\title{
10 CFR 830 Major Modification Determination for ATR Diesel Bus (E-3) and Switchgear Replacement
}

May 2011



The INL is a U.S. Department of Energy National Laboratory operated by Battelle Energy Alliance 
INL/EXT-11-22062

\title{
10 CFR 830 Major Modification Determination for ATR Diesel Bus (E-3) and Switchgear Replacement
}

May 2011

\author{
Idaho National Laboratory \\ Idaho Falls, Idaho 83415
}

http://www.inl.gov

Prepared for the

U.S. Department of Energy

Office of Nuclear Energy

Under DOE Idaho Operations Office

Contract DE-AC07-05ID14517 
INL/EXT-11-22062

Revision 0

\section{DISCLAIMER}

This information was prepared as an account of work sponsored by an agency of the U.S. Government. Neither the U.S. Government nor any agency thereof, nor any of their employees, makes any warranty, expressed or implied, or assumes any legal liability or responsibility for the accuracy, completeness, or usefulness, of any information, apparatus, product, or process disclosed, or represents that its use would not infringe privately owned rights. References herein to any specific commercial product, process, or service by trade name, trade mark, manufacturer, or otherwise, does not necessarily constitute or imply its endorsement, recommendation, or favoring by the U.S. Government or any agency thereof. The views and opinions of authors expressed herein do not necessarily state or reflect those of the U.S. Government or any agency thereof. 
INL/EXT-11-22062

Revision 0

\title{
Advanced Test Reactor
}

\section{CFR 830 Major Modification Determination \\ for}

\section{ATR Diesel Bus (E-3) and Switchgear Replacement}

\author{
INL/EXT-11-22062
}

Revision 0

May 2011

Developed by:
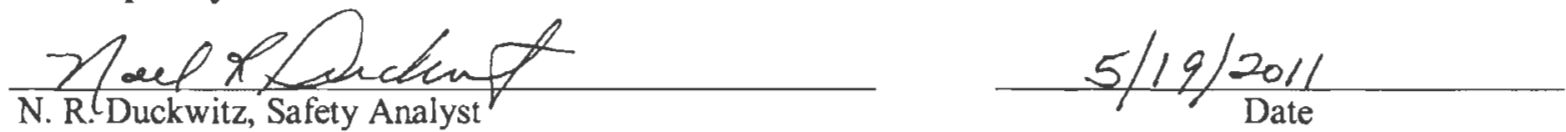

Approved by:
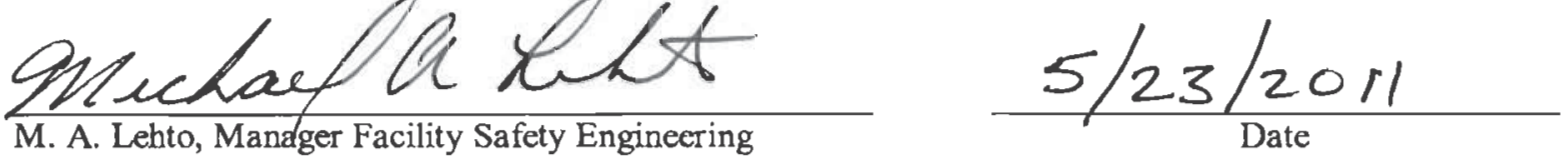

M. A. Lehto, Manager Facility Safety Engineering
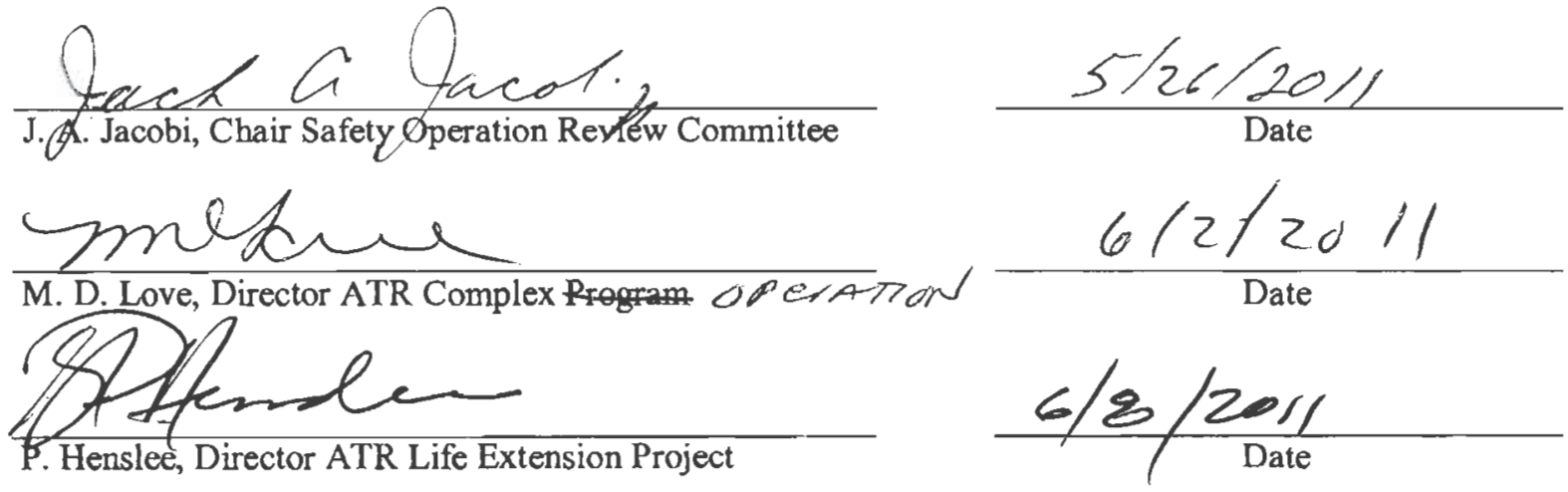


\section{CONTENTS}

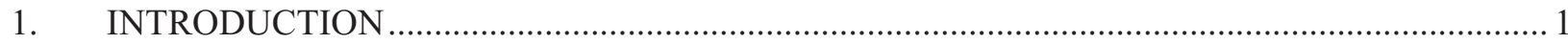

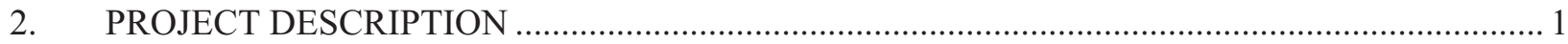

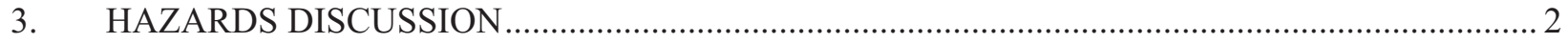

4. MAJOR MODIFICATION EVALUATION CRITERIA …..................................................... 3

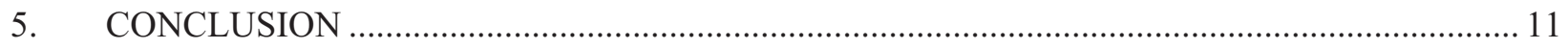



TABLES

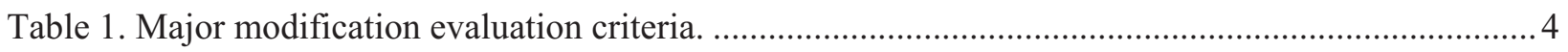

FIGURES

Figure 1. Facility modification process (taken from DOE-STD-1189, Figure 8-1)................................ 10 


\section{DEFINITIONS}

Major modification - A modification to a DOE nuclear facility that is completed on or after May 9, 2001 that substantially changes the existing safety basis for the facility. (10 CFR 830)

Nuclear facility - A reactor or a nonreactor nuclear facility where an activity is conducted for or on behalf of DOE and includes any related area, structure, facility, or activity to the extent necessary to ensure proper implementation of the requirements established by 10 CFR 830. (10 CFR 830)

Safety basis - The documented safety analysis and hazard controls that provide reasonable assurance that a DOE nuclear facility can be operated safely in a manner that adequately protects workers, the public, and the environment. (10 CFR 830)

Simple modification - A modification to a DOE nuclear facility not requiring a new or revised hazard analysis and accident analysis and new safety controls. (DOE-STD-1189)

Substantial change to the existing safety basis - Required by facility modification that is considered a major modification. (DOE-STD-1189) 


\section{ACRONYMS and ABBREVIATIONS}

ATR

CDF

CFR

CSDR

DOE

EEB

GFE

$\mathrm{HC}$

INL

MAR

MCA

$\mathrm{NE}$

$\mathrm{NPH}$

OEM

PC

PDSA

PSDR

SAR

$\mathrm{SC}$

SDS

SS

SSC

STD

TFR

UFSAR

UPS
Advanced Test Reactor

core damage frequency

Code of Federal Regulation

conceptual safety design report

U.S. Department of Energy

electrical equipment building

government furnished equipment

hazard category

Idaho National Laboratory

material at risk

material condition assessment

Office of Nuclear Energy

natural phenomena hazards

original equipment manufacturer

performance category

preliminary documented safety analysis

preliminary safety design report

safety analysis report

safety class

safety design strategy

safety significant

structure, system or component

standard

technical and functional requirements

updated final safety analysis report

uninterruptible power supply 
INL/EXT-11-22062

Revision 0

\section{CFR 830 Major Modification Determination for the}

\section{ATR Diesel Bus (E-3) and Switchgear Replacement}

\section{INTRODUCTION}

The Advanced Test Reactor (ATR), located in the Advanced Test Reactor Complex of the Idaho National Laboratory (INL), was constructed in the 1960s for the purpose of irradiating reactor fuels and materials. Other irradiation services, such as radioisotope production, are also performed at ATR.

The continued safe and reliable operation of the ATR is critical to the Department of Energy (DOE) Office of Nuclear Energy (NE) mission. While ATR is safely fulfilling current mission requirements, a variety of aging and obsolescence issues challenge ATR engineering and maintenance personnel's capability to sustain ATR over the long term. First documented in a series of independent assessments, beginning with an OA Environmental Safety and Health Assessment conducted in 2003, the issues were validated in a detailed Material Condition Assessment (MCA) conducted as a part of the ATR Life Extension Program in 2007. Accordingly, near term replacement of aging and obsolescent original ATR equipment has become important to ensure ATR capability in support of NE's long term national missions. To that end, a mission needs statement has been prepared for a non-major system acquisition which is comprised of three interdependent subprojects. The first project, subject of this determination, will replace the existent diesel-electrical bus (E-3) and associated switchgear. More specifically, INL proposes transitioning ATR to 100\% commercial power with appropriate emergency backup to include:

- Provide commercial power as the normal source of power to the ATR loads currently supplied by diesel-electric power.

- Provide backup power to the critical ATR loads in the event of a loss of commercial power.

- Replace obsolescent critical ATR power distribution equipment, e.g., switchgear, transformers, motor control centers, distribution panels.

Completion of this and two other age-related projects (primary coolant pump and motor replacement and emergency firewater injection system replacement) will resolve major age-related operational issues plus make a significant contribution in sustaining the ATR safety and reliability profile.

\section{PROJECT DESCRIPTION}

This project description is based on the drafted Mission Need Statement for ATR Reliability Sustainment Project ${ }^{1}$ and the pre-conceptual phase technical and function requirements for transition of ATR to $100 \%$ commercial power. ${ }^{2}$ (Note that further system studies may identify the need for changes.)

Experience with commercial power in Eastern Idaho in the late 1950s, during ATR design, demonstrated that even mild weather phenomena could disturb the available commercial power delivery systems resulting in frequent power outages for both domestic and commercial users. The high likelihood of power disruptions mandated the plant's designers incorporate a diesel electric bus in the ATR design to ensure the availability of reliable continuous power for plant safety systems and heat removal in the event of unplanned commercial power disruption. Mitigation was provided through installation of a diesel-electric bus (switchgear) supplied by diesel generators designed to run continuously during plant operations. The prime movers were (and are) large low speed marine diesels of what is now an antiquated design with severely limited vendor support. The marine diesels are backed up by a safety-related standby diesel generator 674-M-6. The diesel electric bus provides all necessary safety-related power to 
accommodate unplanned shutdowns and necessary core heat removal. Today, however, the prime movers are, through age, rapidly becoming the source of reliability issues that can impair mission accomplishment.

Commercial power availability at the INL is now, itself, significantly more reliable than that available at the time of ATR design and construction. Transition to available and reliable commercial power with appropriate and available emergency backup emergency power systems will allow retirement of the 50 -year-old emergency diesels, no longer original equipment manufacturer (OEM) supported. With this project, commercial power will replace continuous-run diesel generators as the normal power source for the safety-related $670-\mathrm{E}-3,4.16 \mathrm{kV}$ "diesel bus." In the event of loss of commercial power, the safety-related bus will receive seamless, reliable power from a safety-related uninterruptible power supply (UPS) and two safety-related quick start diesel generators. The two diesel generators will provide triple redundancy with the current safety-related standby diesel generator 674-M-6 that currently backs up the normal continuous run, diesel power.

This project will also replace the aged, E-3 670-E-3 "diesel bus" and switchgear with modern equipment. The safety-related E-3 bus/switchgear, safety-related UPS, two safety-related quick start diesel generators, and supporting unitized power centers for each diesel generator will be located in a new electrical equipment building (EEB). The EEB will be a separate building built near the reactor building, designed to Performance Category 4 (PC-4) standards, inclusive of all building support systems. PC-4 standards are to be maintained to the point of connection to the current ATR electrical distribution system.

This project may also replace the two existing 13.8 to $4.16 \mathrm{kV}$ commercial transformers. Based on MCA findings, the two existing 13.8 to $4.16 \mathrm{kV}$ commercial transformers are also nearing the end of their design service life. No longer supported by OEMs, transformer maintenance activities are becoming increasingly difficult and, due to their oil-cooled design, the old transformers are unnecessarily hazardous to ATR staff compared to currently available replacement equipment. The old oil-filled transformers also present fire hazards most readily mediated through replacement with modern, current design, replacement transformers.

\section{HAZARDS DISCUSSION}

\section{Material at Risk}

The ATR material at risk (MAR) consists of the reactor core, the radioactive materials (irradiated fuel elements and other hardware) stored in the canal, isotope production targets, and experiments containing fuel and non-fueled components. The ATR is a Category A reactor with an operating power level up to $250 \mathrm{MW}_{\mathrm{t}}$ and, as such, has a radioactive material inventory with the potential for significant off-site consequences. The proposed project has no effect on the quantity of MAR.

\section{Fires and/or Explosions}

The new EEB facility diesel generators, associated diesel generator fuel tanks, UPS, and switchgear include inherent fire/explosion hazards that will be minimized through the proper design and selection of construction materials. Recharging of the UPS batteries introduces the explosion hazard associated with hydrogen generation. Any fire or explosion associated with these components will not introduce any new mechanism for release of radioactive material from ATR; however, the impact to the safety function for the safety-related components will need to be evaluated to ensure the design is adequate to preclude adverse impact to the reactor safety (e.g. core damage frequency $[\mathrm{CDF}]$ ).

\section{Natural Phenomena Hazards}

Natural phenomena hazards (NPHs), including earthquakes (seismic events), extreme wind, tornado, flood, volcanic, and lightning, are potential hazards to the facility for causing building damage and/or 
failure of safety-related operational equipment. These NPH hazards were evaluated in SAR-153 for existing facilities in support of current operations. The pre-conceptual phase technical and function requirements (TFR) document ${ }^{2}$ for this project includes NPH criteria for the building and equipment consistent with the anticipated safety classification.

\section{MAJOR MODIFICATION EVALUATION CRITERIA}

DOE-STD-1189, "Integration of Safety into the Design Process," 3 was developed to provide consistent DOE complex-wide criteria to be used in determining if a change constitutes a major modification. The standard includes Table 8-1, "Major Modification Evaluation Criteria." The table provides a methodology for evaluating a project against the 10 CFR830 major modification evaluation criteria $^{4}$ and was used as a basis for this major modification determination. The table is reproduced herein as Table 1, "Major Modification Evaluation Criteria." The purpose of Table 1 is to focus on the nature of the modification and the associated impact on the existing facility safety basis for the ATR facility.

Major modifications are defined as those changes that "substantially change the existing safety basis for the facility." The guidance for applying the table states that in applying the criteria, the intent is not to automatically trigger the need for a preliminary documented safety analysis (PDSA) if one or more of the criteria are met. Rather, it is intended that each criterion be assessed individually and then an integrated evaluation be performed based on the collective set of individual results. In performing this evaluation, the focus should be on the nature of the modification and its associated impact on the existing facility safety basis. Even a project that results in changes that ripple through the safety basis documents does not "substantially change the existing safety basis for the facility" solely because many parts or pages of the safety basis documentation need to be revised.

A major modification requires the development of a PDSA, per 10 CFR 830.206, following the facility modification process as depicted in Figure 1. Since DOE-STD-3009, "Preparation Guide for U. S. Department of Energy Nonreactor Nuclear Facility Documented Safety Analyses," is not the safe harbor format for the ATR Updated Final Safety Analysis Report (UFSAR), the safety design strategy (SDS) must establish the expectations and the format for integrating the subject major modifications to the update of the UFSAR. 
Table 1. Major modification evaluation criteria.

\section{Major Modification Evaluation Criteria (DOE-STD-1189, Table 8-1)}

\section{Project Information}

The proposed project will transition ATR to $100 \%$ commercial power at a TEC of $\$ 65 \mathrm{~m}$. A new EEB will be constructed to house two safety-related, quick-start diesel generators, a safety-related UPS, and a replacement bus/switchgear for the aged, safetyrelated, E-3 diesel bus. Commercial power, backed up with the diesel generators and UPS, will provide continuous power to the replacement E-3 bus. The commercial power will be the normal power source for the E-3 bus and replace the existing, aged continuous run diesel generators which will be retired in-place.

In addition to installing a replacement E-3 bus, the two aged 13.8 to $4.16 \mathrm{kV}$ transformers for the ATR Complex may be replaced.

\begin{tabular}{|c|l|l|l|}
\hline $\begin{array}{c}\text { Evaluation } \\
\text { Criterion } \\
\text { No. }\end{array}$ & $\begin{array}{l}\text { Evaluation } \\
\text { Criteria }\end{array}$ & DOE-STD-1189 Discussion & ATR Diesel Bus (E-3) and Switchgear Replacement Discussion \\
\hline 1 & $\begin{array}{l}\text { Add a new } \\
\text { building or } \\
\text { facility with a } \\
\text { material } \\
\text { inventory } \geq \\
\text { Hazard } \\
\text { Category } 3 \\
\text { (HC 3) limits } \\
\text { or increase } \\
\text { the HC of an } \\
\text { existing } \\
\text { facility? }\end{array}$ & $\begin{array}{l}\text { A new building may be a } \\
\text { structure within an existing } \\
\text { facility segment. That structure } \\
\text { may or may not have direct } \\
\text { process ties to the remainder of } \\
\text { the segment/process. The } \\
\text { requirements of } \\
\text { DOE-STD-1027-92, Change } \\
\text { Notice 1, September 1997, are } \\
\text { used in evaluating hazard } \\
\text { categorization impacts. }\end{array}$ & $\begin{array}{l}\text { No, it does not change the HC of the existing facilities and, by itself, is a } \\
\text { non-radiological facility. } \\
\text { The proposed modification adds a new stand-alone EEB to house the } \\
\text { project's replacement components and provide space for future } \\
\text { replacement of current ATR switchgear, motor control centers, and } \\
\text { associated electrical equipment. The building is physically separate from } \\
\text { the ATR reactor building and will not hold any radiological inventory (i.e., } \\
\text { will be a non-radiological building); however, it will be one of the } \\
\text { buildings/structures that make up the ATR Complex Advanced Test } \\
\text { Reactor as currently listed in the Upgraded Final Safety Analysis } \\
\text { (UFSAR). }\end{array}$ \\
structures are necessary for safe operation of ATR.
\end{tabular}




\begin{tabular}{|c|c|c|c|}
\hline $\begin{array}{c}\text { Evaluation } \\
\text { Criterion } \\
\text { No. }\end{array}$ & $\begin{array}{c}\text { Evaluation } \\
\text { Criteria }\end{array}$ & DOE-STD-1189 Discussion & ATR Diesel Bus (E-3) and Switchgear Replacement Discussion \\
\hline 2 & $\begin{array}{l}\text { Change the } \\
\text { footprint of an } \\
\text { existing HC 1, } \\
2 \text { or } 3 \text { facility } \\
\text { with the } \\
\text { potential to } \\
\text { adversely } \\
\text { affect any } \\
\text { safety class } \\
\text { (SC) or safety } \\
\text { significant } \\
\text { (SS) safety } \\
\text { function or } \\
\text { associated } \\
\text { structure, } \\
\text { system and } \\
\text { component } \\
\text { (SSC)? }\end{array}$ & $\begin{array}{l}\text { A change in the footprint of an } \\
\text { existing facility requires the } \\
\text { identification and evaluation of } \\
\text { any potential adverse impacts } \\
\text { on SC or SS safety functions or } \\
\text { associated SSC (e.g., structural } \\
\text { qualification, evacuation egress } \\
\text { path, fire suppression spray } \\
\text { pattern) or safety analysis } \\
\text { assumptions. Changes that may } \\
\text { involve adverse impacts require } \\
\text { careful attention to maintaining } \\
\text { adherence to applicable } \\
\text { engineering standards and } \\
\text { nuclear safety design criteria. }\end{array}$ & $\begin{array}{l}\text { Yes. The footprint of buildings and structures that make up the ATR } \\
\text { Complex Advanced Test Reactor are listed in Section } 5.2 \text { of NS-18303, } \\
\text { "INL Nuclear Facilities and Nuclear Facility Managers." The new, EEB } \\
\text { will be added to the list and be an addition to the "footprint" for the HC1 } \\
\text { ATR reactor. As stated in Section } 2.4 \text { of the pre-conceptual phase TFR } \\
\text { document, } 30054.046-2 \text {, all systems and components for the replacement } \\
\text { E-3 bus, including two quick start diesel generators and UPS, perform a } \\
\text { safety function. Likewise, the new EEB that houses the replacement E-3 } \\
\text { bus and the associated equipment and components also performs a } \\
\text { safety function. Safety classification will be determined by INL based on } \\
\text { the safety analysis/probabilistic risk assessment. }\end{array}$ \\
\hline
\end{tabular}




\begin{tabular}{|c|c|c|c|}
\hline $\begin{array}{c}\text { Evaluation } \\
\text { Criterion } \\
\text { No. }\end{array}$ & $\begin{array}{c}\text { Evaluation } \\
\text { Criteria }\end{array}$ & DOE-STD-1189 Discussion & ATR Diesel Bus (E-3) and Switchgear Replacement Discussion \\
\hline 3 & $\begin{array}{l}\text { Change an } \\
\text { existing } \\
\text { process or } \\
\text { add a new } \\
\text { process } \\
\text { resulting in the } \\
\text { need for a } \\
\text { safety basis } \\
\text { change } \\
\text { requiring DOE } \\
\text { approval? }\end{array}$ & $\begin{array}{l}\text { A change to an existing process } \\
\text { may negatively affect the } \\
\text { efficacy of an approved set of } \\
\text { hazard controls for a given event } \\
\text { or accident. Likewise, potential } \\
\text { safety concerns associated with } \\
\text { a new process may not be } \\
\text { adequately addressed by the } \\
\text { existing approved control sets. } \\
\text { In this case, it is assumed that } \\
\text { the existing analyses addressed } \\
\text { the hazards associated with the } \\
\text { new or revised process, but the } \\
\text { specified control set(s) may no } \\
\text { longer be valid. The evaluation } \\
\text { of any new hazards introduced } \\
\text { by the revised or new process } \\
\text { should be addressed via } \\
\text { Criterion } 6\end{array}$ & $\begin{array}{l}\text { Yes. The proposed activity does change an existing process resulting in a } \\
\text { safety basis change that requires DOE approval. } \\
\text { The current process is to provide continuous diesel generator power to } \\
\text { the safety-related } 4.16 \mathrm{kV} \text { diesel bus } 670-\mathrm{E}-3 \text {. Currently diesel generator } \\
\text { power is provided through continuous operation of the two } \\
\text { non-safety-related diesel generators } 670-\mathrm{M}-42 \text { or } 670-\mathrm{M}-43 \text { or, upon their } \\
\text { failure, startup and loading (within } 20 \text { seconds) of the safety-related } \\
\text { standby diesel generator } 674-\mathrm{M}-6 \text {. The safety-related } 4.16 \mathrm{kV} \text { diesel bus } \\
670-\mathrm{E}-3 \text { supplies power through a safety-related step down transformer } \\
670-E 8 \text { to the safety-related } 480 \mathrm{~V} \text { diesel bus } 670-\mathrm{E} 9 \text { that supplies power } \\
\text { through safety-related automatic transfer switch ATS } 670-\mathrm{E}-228 \text { to the } \\
\text { diesel commercial bus } 670-\mathrm{E}-15 \text {. The diesel commercial bus provides } \\
\text { power for the safety-related emergency coolant pump } 670-\mathrm{M}-10 \text {. } \\
\text { Per the pre-conceptual TFR for the transition to } 100 \% \text { commercial power } \\
\text { distribution, the obsolete non-safety-related diesel generators } 670-\mathrm{M}-42 \\
\text { and } 670-\mathrm{M}-43 \text { will be retired. The continuous diesel generator power to } \\
\text { bus } 670-\mathrm{E}-3 \text { will be replaced with normal commercial power. Commercial } \\
\text { power and an UPS (expected to be classified safety-related) will provide } \\
\text { seamless power to the bus until, in the event of a loss of commercial } \\
\text { power, the safety-related diesel generator } 674-\mathrm{M}-6 \text { picks up the load. Two } \\
\text { quick start diesel generators (expected to be classified safety-related) will } \\
\text { provide redundancy to } 674-\mathrm{M}-6 \text {. The diesel generators, UPS, and } \\
\text { replacement for the } 4.16 \mathrm{kV} \text { diesel bus } 670-\mathrm{E}-3 \text { will be located in a new } \\
\text { EEB with the appropriate safety/seismic classification for a facility housing } \\
\text { safety-related equipment. }\end{array}$ \\
\hline
\end{tabular}




\begin{tabular}{|c|c|c|c|}
\hline $\begin{array}{c}\text { Evaluation } \\
\text { Criterion } \\
\text { No. }\end{array}$ & $\begin{array}{c}\text { Evaluation } \\
\text { Criteria }\end{array}$ & DOE-STD-1189 Discussion & ATR Diesel Bus (E-3) and Switchgear Replacement Discussion \\
\hline 4 & $\begin{array}{l}\text { Utilize new } \\
\text { technology or } \\
\text { government } \\
\text { furnished } \\
\text { equipment } \\
\text { (GFE) not } \\
\text { currently in } \\
\text { use or not } \\
\text { previously } \\
\text { formally } \\
\text { reviewed / } \\
\text { approved by } \\
\text { DOE for the } \\
\text { affected } \\
\text { facility? }\end{array}$ & $\begin{array}{l}\text { This assessment should include } \\
\text { consideration of the impact that } \\
\text { the use of new technology } \\
\text { (including technology scale-up } \\
\text { issues) or GFE may have on the } \\
\text { ability to specify the applicable } \\
\text { nuclear safety design criteria } \\
\text { with a high degree of certainty in } \\
\text { the early stages of the project. } \\
\text { Additionally, refer to GFE } \\
\text { discussion in Section } 8.3 \text {. GFE } \\
\text { may have a technical baseline } \\
\text { that is not directly and fully } \\
\text { supportive of the project } \\
\text { functional and performance } \\
\text { requirements. An example } \\
\text { would be employing a new } \\
\text { technology for removal of certain } \\
\text { nuclides from a waste stream. }\end{array}$ & $\begin{array}{l}\text { No. The proposed activity will utilize like-for-like, functionally equivalent } \\
\text { replacement equipment that is current technology to the nuclear power } \\
\text { industry. Diesel generators } 670-\mathrm{M}-42 \text { and } 670-\mathrm{M}-43 \text { are low speed marine } \\
\text { diesels of what is now an antiquated design with severely limited vendor } \\
\text { support. They will be replaced with normal commercial power and } \\
\text { available backup emergency power systems (an UPS with two quick start } \\
\text { diesels). Replacement buses/switchgear and transformers employ } \\
\text { commercially accepted, current technology. }\end{array}$ \\
\hline
\end{tabular}


INL/EXT-11-22062

Revision 0

\begin{tabular}{|c|c|c|c|}
\hline $\begin{array}{c}\text { Evaluation } \\
\text { Criterion } \\
\text { No. }\end{array}$ & $\begin{array}{c}\text { Evaluation } \\
\text { Criteria }\end{array}$ & DOE-STD-1189 Discussion & ATR Diesel Bus (E-3) and Switchgear Replacement Discussion \\
\hline 5 & $\begin{array}{l}\text { Create the } \\
\text { need for new } \\
\text { or revised } \\
\text { safety SSCs? }\end{array}$ & $\begin{array}{l}\text { Consideration should be given } \\
\text { to the relative complexity of the } \\
\text { controls and the ease with which } \\
\text { the controls can be } \\
\text { implemented. The use of a } \\
\text { complicated multi-channel } \\
\text { Safety Class seismically } \\
\text { qualified instrumented system to } \\
\text { provide multiple interlock and } \\
\text { alarm functions would typically } \\
\text { pose a higher risk to the project } \\
\text { than the use of a safety } \\
\text { significant passive design } \\
\text { feature. The degree of design } \\
\text { and regulatory uncertainty } \\
\text { should be addressed for this } \\
\text { criterion for the development, } \\
\text { review, and approval of new or } \\
\text { revised safety analysis and } \\
\text { attendant controls (e.g., } \\
\text { presence of multiple } \\
\text { regulatory/technical agencies on } \\
\text { a single project). }\end{array}$ & $\begin{array}{l}\text { Yes. It is expected that the proposed activity will result in a revised list of } \\
\text { safety-related SSCs. Specifically, based on the pre-conceptual TFR, it is } \\
\text { anticipated that the following SSCs will be added to the credited list of } \\
\text { safety SSCs: } \\
\text { - The replacement } 4.16 \mathrm{kV} \text { diesel bus } \\
\text { - The UPS } \\
\text { - The two additional quick-start } 4.16 \mathrm{kV} \text { diesel generators and } \\
\text { associated power coordination/distribution controls } \\
\text { - The EEB housing these systems }\end{array}$ \\
\hline
\end{tabular}




\begin{tabular}{|c|c|c|c|}
\hline $\begin{array}{c}\text { Evaluation } \\
\text { Criterion } \\
\text { No. }\end{array}$ & $\begin{array}{c}\text { Evaluation } \\
\text { Criteria }\end{array}$ & DOE-STD-1189 Discussion & ATR Diesel Bus (E-3) and Switchgear Replacement Discussion \\
\hline 6 & $\begin{array}{l}\text { Involve a } \\
\text { hazard not } \\
\text { previously } \\
\text { evaluated in } \\
\text { the } \\
\text { Documented } \\
\text { Safety } \\
\text { Analysis? }\end{array}$ & $\begin{array}{l}\text { Hazards can include the } \\
\text { introduction of an accident or } \\
\text { failure mode of a different type } \\
\text { from that previously analyzed in } \\
\text { addition to radiological or } \\
\text { toxicological hazards. The need } \\
\text { to address a new hazard early in } \\
\text { the design process may lead to } \\
\text { some degree of uncertainty } \\
\text { related to the proper } \\
\text { specification of applicable } \\
\text { nuclear safety design criteria. In } \\
\text { such cases, this uncertainty } \\
\text { should be addressed within this } \\
\text { evaluation. }\end{array}$ & $\begin{array}{l}\text { Yes. The proposed activity does introduce a large UPS located in the new } \\
\text { EEB with the safety-related E-3 diesel bus. The charging of the UPS } \\
\text { batteries does introduce concerns with hydrogen generation which, } \\
\text { although not unique to the proposed activity, will need to be evaluated. In } \\
\text { addition, the ATR probabilistic risk assessment will have to be updated to } \\
\text { confirm that the proposed activity meets its objective to maintain or } \\
\text { reduce the CDF for the ATR. It is anticipated that the increased reliability } \\
\text { of commercial power with the addition of the UPS and two additional quick } \\
\text { start diesel generators will achieve the CDF objective; however, the ATR } \\
\text { probabilistic risk assessment will have to be updated to confirm the } \\
\text { objective is met. }\end{array}$ \\
\hline \multicolumn{4}{|c|}{$\begin{array}{l}\text { Summary and Recommendation: Four of the six criteria (Criterion 2, 3, } 5 \text { and } 6 \text { ) were tripped in this major modification evaluation. As discussed } \\
\text { above, the proposed project does not introduce any new significant hazards (other than UPS } \mathrm{H}_{2} \text { generation) requiring new accident analyses. } \\
\text { However, the proposed strategy for providing reliable power for the safety-related emergency cooling pumps requires the designation of new } \\
\text { equipment (quick start diesels and UPS) as safety-related SSCs. The safety-related designation requires careful attention to maintaining } \\
\text { adherence to applicable engineering and nuclear safety design criteria (e.g., seismic qualification, isolation of redundant trains from common } \\
\text { fault failures) to ensure no adverse impacts to their designated safety functions. Based on these considerations, it is concluded that this project } \\
\text { constitutes a major modification and will, therefore, require the development, review, and approval of a PDSA. It is recommended that the } \\
\text { project proceed accordingly. Also, since DOE-STD-3009 is not the safe harbor format for the ATR UFSAR, the SDS must establish the } \\
\text { expectations and the format for the preliminary safety design report (PSDR) (if needed) and PDSA to integrate the subject major modifications } \\
\text { into the ATR UFSAR. }\end{array}$} \\
\hline
\end{tabular}


INL/EXT-11-22062

Revision 0



Figure 1. Facility modification process (taken from DOE-STD-1189, Figure 8-1). 


\section{CONCLUSION}

The major modification criteria evaluation of the project pre-conceptual design identified several issues make the project a major modification:

1. Evaluation Criteria \#2 (Footprint change). The addition of a new PC-4 structure to the ATR Facility to house safety-related SSCs requires careful attention to maintaining adherence to applicable engineering and nuclear safety design criteria (e.g., structural qualification, fire suppression) to ensure no adverse impacts to the safety-related functions of the housed equipment.

2. Evaluation Criteria \#3 (Change of existing process). The change to the strategy for providing continuous reliable power to the safety-related emergency coolant pumps requires careful attention and analysis to ensure it meets a project primary object to maintain or reduce CDF and does not negatively affect the efficacy of the currently approved strategy.

3. Evaluation Criteria \#5 (Create the need for new or revised safety SSCs). The change to the strategy for providing continuous reliable power to the safety-related emergency coolant pumps, based on the pre-conceptual design, will require the addition of two quick start diesel generators, their associated power coordination/distribution controls, and a UPS to the list of safety-related SSCs. Similarly to item 1 above, the addition of these active SSCs to the list of safety-related SSCs and replacement of the E-3 bus requires careful attention to maintaining adherence to applicable engineering and nuclear safety design criteria (e.g., seismic qualification, isolation of redundant trains from common fault failures) to ensure no adverse impacts to the safety-related functions.

As discussed in 1, 2, and 3 above, the positive major modification determination is driven by the need to carefully establish the engineering and nuclear safety design criteria for new safety-related SSCs and structures. Since the proposed project does not introduce significant new hazards, the safety analysis will need to be tailored appropriately as discussed in the following text from DOE-STD-1189, Chapter 8:

"Where a major modification is found to exist, an SDS must be developed that addresses (1) the need for a CSDR or PSDR (as well as the required PDSA) to support project phases, (2) the graded content of the PDSA necessary to support the design and modification, (3) the application of nuclear safety design criteria, and (4) the interface with the existing facility, its operations, and construction activities."

\section{REFERENCES}

1. Mission Need Statement for Advanced Test Reactor Reliability Sustainment Project, March 2011 Draft.

2. Doc. ID 30054.046-2, "Transition the Advanced Test Reactor (ATR) to 100\% Commercial Power, Technical and Functional Requirements (Pre-Conceptual Phase)," URS Corporation, September 2010.

3. DOE-STD-1189-2008, "Integration of Safety into the Design Process," Department of Energy, March 2008.

4. 10 CFR 830, Subpart B, "Nuclear Safety Management," Code of Federal Regulations, Office of the Federal Register, current revision.

5. DOE-STD-3009-94, Change 3, "Preparation Guide for U. S. Department of Energy Nonreactor Nuclear Facility Documented Safety Analyses," Department of Energy, March 2006. 
INL/EXT-11-22062

Revision 0

6. SAR-153, "Upgraded Final Safety Analysis Report for the Advanced Test Reactor," Rev. 30, February 2011.

7. NS-18303, "INL Nuclear Facilities and Nuclear Facility Managers," current revision. 